\title{
Choice and the impact of changes to Sunday premiums in the Australian retail and hospitality industries
}

\section{Background}

The purpose of this paper is to assess the effects of reductions in wage premiums for Sunday work. We do this in the context of a recent decision by Australia's Fair Work Commission (FWC) to reduce Sunday premiums, public holiday premiums and a small number of nightwork premiums — collectively known as 'penalty rates' — in the retail and hospitality industries. Internationally, these industries have a high incidence of non-standard working hours and, partly because of difficulties in union organisation, they are amongst those most vulnerable to reductions in premiums. For example, in New Zealand in the 1990s, 'penal rates' (that country's equivalent) in the retail sector were almost universally terminated by employers when national legislative changes removed many of the minimum standards arising from employment law (Peetz et al. 1993). Not all countries even have Sunday work in those industries - for example, in Germany most larger retailers are prohibited from opening on Sundays, and families are forced by social pressure to spend time together instead, in such activities as cycling, walking or eating - but for those that do, the question of weekend premiums in general, and Sunday premiums in particular, is an important matter. Premiums for non-standard working time in Australia are set not be statute but by 'awards', legally binding instruments established by tribunals (mostly the FWC) that set out minimum pay and conditions in a range of occupations and industries. A detailed assessment of the FWC's decision has been undertaken for this journal by McIvor and Markey (2017), which focuses on secondary evidence on the ongoing importance of Sundays and the effects of the 
FWC decision on employment, so this paper presents some primary evidence on the implications for employees in the context of notions of 'choice' and some indication of the numbers affected and the manner of the impact. Primary evidence on the employment effects is also considered elsewhere (Yu and Peetz 2018).

More detail on the specifics of the February 2017 FWC decision on penalty rates is provided by McIvor and Markey (2017), but broadly speaking it can be characterised thus. The decision (Fair Work Commission 2017a) had the effect of reducing penalty rates by up to a quarter in the retail and hospitality industries. The most important change was a reduction in the Sunday rate for full-time and part-time employees under the Retail Award from 200 to 150 per cent of the ordinary wage (that is, after the decision, Sunday retail employees received 1.5 times the minimum pay of weekday employees).. For full-time and part-time employees under the Pharmacy Award, a similar reduction was applied, while for such employees under the Hospitality Award, the reduction was from 175 to 150 per cent, and for level 1 employees in the Fast Food Award from 150 to 125 per cent. Casual employees typically experienced a reduction of 25 percentage points, from 200 per cent in the Retail and Pharmacy awards, and from 175 per cent in the Fast Food Award, such that their Sunday penalty rate ended up 25 per cent age points higher than that for permanent (full-time and part-time) workers.

The 2017 decision followed from an earlier (2014) decision to reduce Sunday penalty rate for level 1 and 2 casual restaurant workers from 175 per cent to 150 per cent, bringing it in line with the Saturday rate ([2014] FWCFB 1996). No further changes were made to the Restaurant Award's weekend rates in the 2017 decision, but the idea of reducing rates for low-classification employees was, as mentioned, also adopted in the Fast Food Award. 
Public holiday penalty rates were reduced in the Restaurant Award—as they were in most retail and hospitality awards - from 250 to 225 per cent (plus an extra 25 per cent for casuals).

Several factors seemed to influence the FWC's decision. It was persuaded that there will be some 'employment' effects, but these were unquantifiable due to the conflicting evidence presented. The FWC acknowledged 'disutilities' associated with working on Sundays, and that these were worse than working on Saturdays, but by much less than in the past. Implicit in the idea that the 'disutilities' of Sunday work are less than they were, and explicit in some of the employer evidence, is the notion that Sunday workers in retail and hospitality have choice as to when they work. They choose to be working Sundays, and these choices have, until now, been overly influenced by the inflated pay rates applying on Sundays. The FWC decision referred to 'the fact that employees are exercising a choice, albeit one that is constrained by other considerations' [at 539]. It observed that a 'significant contextual matter' was that 'the disutility in relation to public holidays has been ameliorated somewhat by the introduction of the statutory right to refuse to work on such days, on reasonable grounds' [at 76 and 436] and rejected a proposal that, if penalty rates were abused, it should provide that all Sunday work by voluntary as 'such a term' would not be 'necessary' [at 1997].

This article assesses the some key ideas behind the FWC decision, first by reference to evidence from $\mathrm{ABS}$ and other quantitative data about its likely impact, and second by reference to qualitative data concerning the nature of the choices available to Sunday workers in those industries. We ask: Who are retail and hospitality employees? (For example, are 
they mostly students who can 'afford' a cut in penalty rates?) What is the impact of the decision upon them? What are the motivations of, and choices available to weekend workers in retail and hospitality in Australia? What are these employees' preferences, and why?

\section{History and literature}

The day of rest or celebration has been around for a long time. In ancient Babylon, the $7^{\text {th }}$, $14^{\text {th }}, 21^{\text {st }}$ and $28^{\text {th }}$ days of a month were 'holy days' on which certain activities were prohibited. In ancient Rome, the seventh day of the week, referred to as the 'day of the Sun', had become the day when wages were traditionally paid to workers, leading it to be seen as a day of celebration, thanks and even rest (History Channel 2017). Some parts of the Roman empire had eight day weeks, though, so in AD 321, Emperor Constantine, who became the first purportedly Christian emperor, decreed the seven-day week, and the day of the Sun as the day for worship and rest. He also, shortly later, decreed that soothsayers, who studied the entrails of human victims, should be consulted in times of calamity, so his conversion was far from complete, and he wisely chose to align the Christian and pagan celebrations in order to minimise coordination costs in the empire (Andrews 1859). After it was realised that God had to rest after six days of work, it made a lot of sense to standardise a seven-day week. Only farmers could keep working on the day of the Sun. Over time, the Christian church built on the idea. It turned Sunday, as they came to call it, into much more a day of rest than celebration, as worship was best done while resting, and eventually proclaimed enforced rest on that Sabbath day. In 1650 the first laws appeared in the United States forbidding Sunday work (MacKinnon 2015). Such laws never became ubiquitous throughout the Christian world, but the idea of the need for a day of both rest and worship did. Although days of worship vary between religions, everywhere there is a weekend. 
In nineteenth century Australia, some colonies passed laws requiring employers to pay an additional wage for those employees forced to work on Sundays, to act as a penalty (hence 'penalty rates') or disincentive for profit gained through such obligations, and to compensate employees for the disutility of Sunday work, though the rates were often set by independent bodies such as the Victorian Wages Board. Penalty rates first appeared in a federal award in 1919, became more widespread thereafter, and were introduced throughout the federal award system in 1947. They covered not just Sunday work but also Saturday work and night work, reflecting the fact that the rates were not just concerned with religious observance but, more importantly for workers, with the disadvantage of working unsociable hours - that is, at nights, or on weekends. By then, union pressure for the 40 hour week had been felt for decades; the eight hour day had first been proposed in 1810 and eight hour day movement in Victoria commenced in 1856. At first, half a day off on Saturday was won, eventually a full day. The appearance of penalty rates was always opposed by employers. They had arisen not through the beneficence of industrial tribunals but after campaigns waged by trade unions. The rates varied between awards and times of day and the week, but generally the highest 'penalties' applied to public holidays, particularly those of uniform national significance such as Christmas, followed by Sunday. As time passed, the religious significance of Sundays diminished, but the increasing incidence of two-earner households made it all the more essential to co-ordinate time off on weekends and, in particular, on Sundays.

Through the last quarter of the twentieth century and beyond, employers campaigned to abolish penalty rates, unsuccessfully running cases in various tribunals. From the 1990s, employers could negotiate with unions enterprise bargaining agreements (EBAs) that, in 
effect, traded off reductions in penalty rates (or other conditions) in return for higher base rates of pay. Employers' biggest breakthrough came with the 2006 WorkChoices legislation, which enabled them to unilaterally abolish penalty rates for employees who signed 'Australian Workplace Agreements' (AWAs) or were covered by non-negotiated 'Employer Greenfields Agreements'. Between May and September 2006, 68 per cent of AWAs abolished penalty rates (Davis 2007b, a), and most EGAs in fast food abolished penalty rates (Workplace Express 2006). The defeat of the Howard government in late 2007 was quickly followed by the repeal of that legislated capacity. Employers continued to campaign, with the support of conservative media and politicians, but in the context of the FWC's 'award modernisation' process switched tactics and focused on reducing penalty rates-particularly Sunday rates — in the review of the retail and hospitality awards. While the review was under way, the Abbott government asked the Productivity Commission (PC) to produce a major report on the workplace relations framework. To the surprise of many, but consistent with the political constraints of the time, the PC backed away from recommending fundamental changes to the industrial relations system; however, it recommended major reductions in Sunday penalty rates in the retail and hospitality industries. Its arguments were contestable but not tested in the FWC, yet heavily informed the FWC decision. The decision by employers and the PC to focus on these industries, and on weekends, rather than acrossthe-board both in space and time, as employers had previously attempted and failed at, perhaps reflected a political assessment that resistance in many other industries (particularly in emergency services, which were heavily unionised and in which weekend work was unavoidable) was too great to take on in the first instance. Some observers expected, though, that any precedent set in retail and hospitality would eventually set the tone for the rest of the workforce (Lyons 2015, Peetz 2016). 
Few argue that reducing penalty rates would not cause loss to those directly affected - the FWC conceded its decision would cause 'hardship' (Fair Work Commission 2017a)—but few also sought to quantify the extent of the hardship. That is a purpose of this paper. One other argument, though, is that, in effect, this does not matter. Evidence used by employer organisations, largely accepted by the FWC, argued that most employees in these industries 'choose' to work Sundays to suit their 'flexibility' needs as part of the modern face of dynamic working life particular to these industries (Lewis 2015, Pezzulo 2015). Other studies have reportedly shown that some individuals freely choose to work weekends without making reference to penalty rates, nevertheless these tend to represent only a minority of workers (Deery and Mahony 1995, Charlesworth and Macdonald 2015, Roan and Diamond 2003). Pezzullo claimed 'minor or no' issues regarding weekend work, as 'workers under the relevant awards are particularly unlikely to report significant problems with working weekends' (Pezzullo, 2015 p. 17). She argued (2015, pvi) that weekend workers 'are now more likely to be dependant (sic) students rather than self-supporting', implying that students working Sundays did not have significant financial needs. Lewis (2014), drawing on timeuse ABS survey data from 2006 and an earlier study (Dawkins, Rungie, and Sloan 1986) argued that the changing nature of time-use cultures, lifestyles, and evolving preferences for flexible work routines meant they were more receptive to the demands of the modern consumer economy, particularly with regards to weekends. Hence for Lewis 'the term "unsocial hours" is often used in order to justify the need for compensating differentials (penalty rates) in order to attract employees...Certainly in the days when a typical worker worked full-time, five days per week or more, this may have been true but this is hardly true of the café, restaurant and catering industry' (Lewis, 2014 p. 21). Evidence lodged by employers in the case claimed that 'retailers believe that casuals and part-time employees who generally want to work Sundays would still want to do so without the current penalty 
rate' (Sands 2015,91$)$ and that if penalty rates were removed 'there would be greater choice of shifts available' (Lewis 2014, p.40).

Yet other literature suggests that the notion of choice, and of employee-based control over schedules, is problematic (Campbell and Chalmers 2008, Burgess and MacDonald 1990). For example, Joan, a participant from the Campbell and Charmers (2008) retail study, would wait by the phone for additional employment as her employer allegedly knew that, in her position, she would cover the 'worst' shifts as she 'was the lady who had desperate on her forehead' (p. 494). A majority of those in another study working unsocial hours (56 per cent) did not have their 'flexibility' needs met (Skinner and Pocock 2014b). Woodman (2012) argued that 'there was little evidence of the participants having autonomy to shape their personal timetable of their choosing' (p. 1084). On the question of whether Sundays were worse for workers than Saturdays, the authors of the AWALI study, from the Centre for Work + Life (CWL), concluded: 'Those who work on Saturday and particularly Sunday have worse work life interference — an issue that is relevant to the current debate about penalty rates in Australia' (Skinner and Pocock 2014a). Other Australian studies also showed that Sunday remained a day for family and civic activities, more so than Saturday or any weekday (Craig and Brown 2014, Bittman 2005). Charlesworth and Macdonald (2015) claimed that some workers were adamant in expressing they worked Sundays because 'it was a requirement of their employer they be rostered on the weekend' (p. 18), many stating they had little determining influence in the setting of these schedules and reported feelings of powerlessness regarding their inability to voice opposition and participate social and familial activities. Another said that 'if you cannot work Sundays they probably wouldn't want you there' (p. 18). Overseas studies, moreover, showed that decisions to work non-standard hours results 
from the premium incentives and not worker preferences (Kostiuk 1990, Lanfranchi, Ohlsson, and Skalli 2002). This is consistent with Australian evidence that shift-workers and non-shiftworkers attach similar value to social time (at evenings and weekends) (Baker, Ferguson, and Dawson 2003).

Our proposition about the role of choice in Sunday work is that the genuinely unhindered preferences of employees - their 'internal preference', based on their personal or family circumstances - is only one of three major elements in the decision to work Sundays. Two other factors are important. One is the role of 'financial inducements'. The obvious form of financial inducement is the offering of Sunday premiums ('penalty rates') to try to persuade employees to work Sundays rather than another day. But in more difficult times - and we return to this shortly - the offering of standard wages on Sunday might still be an inducement.

The other critical factor is employer control: if the employer can essentially require that the employee works on Sundays, there is no choice at all and Sundays will be worked as demanded by the employer, regardless of the work-life disutility. Two other elements can strengthen the effectiveness of those two factors. One is underemployment (people wanting to work more hours than they presently work): if workers are seeking more hours than they are currently able to work, then both employer control and financial inducements will be more important. The other, closely related, element is low wages. If wages are low, workers are more likely to need to work more hours to meet their needs; and workers are likely to have low power and less ability to resist employer control. The linkages are depicted in Figure 1, below. 
The idea that certain workers might need to work more hours to meet their needs if wages are low seems counter to much of the labour supply literature in developed countries, as that suggests the existence of an upward-sloping labour supply curve - that is, as wages increase, so does workers' willingness to offer additional labour, since the marginal benefits from additional work exceed those from additional leisure (Evers et al 2008; Meyer 2018; Sharif 2000). (For high income earners, many studies show, the reverse may be the case, as additional income now means the marginal benefits of an hour of leisure exceed that from an hour of extra work (Sharif 2000).) That dominant literature is consistent with the anecdotal experience of one of these researchers: when working students were asked in class how they would respond to a cut in Sunday penalty rates, a number replied that they would stop working Sundays.

However, there is some literature (mostly, but not entirely, from developing countries) suggesting that for very low incomes the labour supply curve may also be downward-sloping, as workers need to work a certain number of hours to achieve a subsistence income (Sharif 2000). The above model would help explain how such a scenario could also operate in lowwage industries in developed countries like Australia.

Our study, then, investigates who is affected by the changes in penalty rates, how many of them there are, what is the magnitude of the effect, and how much choice do those employees have in deciding whether to work Sundays. 


\section{Methodology}

This article broadly uses two approaches: quantitative analyses of various ABS data series; and qualitative study of a small group of retail and hospitality workers. Part of the method for the quantitative analysis is explained here, but other parts are specified later on, as they relate to specific results and may otherwise be easy to forget. We also explain the qualitative approach here.

The term 'hospitality' in this article refers to the accommodation and food services industry (as defined by the ANZSIC industry classification used by the ABS). The Hospitality Industry (General) Award 2010 was the most common modern award used by award-reliant organisations within the accommodation and food services industry in 2013, being used by more than six in 10 award-reliant organisations. In the retail industry, the most common modern award used by award-reliant organisations was the General Retail Industry Award 2010, also being used by more than six in 10 award-reliant organisations in the industry (Fair Work Commission 2017a at [695], [708] and [1425]). 'The impact of the decision' refers not just to the February 2017 decision, though this is by far the major decision. It also includes reference to the earlier decision on the Restaurant Award that also reduced some Sunday penalty rates, and the likely flow-on into the clubs industry, as, in the face of inadequate evidence from the relevant employer bodies, the FWC failed to make changes but invited submissions on either further reviewing weekend penalty rates there or, preferably, abolishing the clubs award and allowing the workers to be covered by the Hospitality Award, where cuts in penalty rates have already occurred. The clubs industry subsequently applied to merge its award into the Hospitality Award. Over a period of time, penalty rates in almost 
all awards in the retail and hospitality industry either have been or will be reduced, and so this article looks at the retail and hospitality industries as a whole.

There is another reason for this approach. Through this article, the analysis depends on the availability of data. ABS industry definitions do not typically correspond identically to awards, though modern awards have a much closer link to ABS-defined awards than was the case under the pre-2010 award system. ABS data are based on surveys, and these are subject to sampling error that follows a random pattern. Data on employees are less readily available than those for employed persons. The labour force survey (LFS), used for estimates of employment, is a survey of households (in this, 'casual' means 'without paid leave entitlements' and 'permanent' means 'with paid leave entitlements') (Australian Bureau of Statistics 6202.0) while the employee, earnings and hours (EEH) survey, used for estimates of award coverage, is a survey of employers (Australian Bureau of Statistics 6306.0). Relative sampling error increases as sample size declines. In several national publications, the ABS sometimes seeks to overcome this resultant imprecision by using trended estimates (for example, of state and national unemployment rates or many series in the national accounts). However, most of the series relied on for this article are not trended.

Data on the characteristics of Saturday and Sunday employees in the retail and hospitality sectors are based on unpublished triennial data from the ABS Forms of Employment Survey (FOES), a supplement to the LFS, conducted in November each year over several years to 2013 (Australian Bureau of Statistics 6359.0). Again, because of sampling error, estimates here have been averaged over three year periods, to improve the accuracy of estimates: where three (annual) estimates have been averaged, the sampling error is reduced by over two fifths. 
To investigate the issue of choice, one of the authors undertook qualitative interviews, using a snowballed sample of 15 Sunday workers from the retail and hospitality industries. This involved workers across Brisbane and the Sunshine Coast, mostly Anglophone, from a range of backgrounds including young adults, students and those with and without dependents.

The interviewees included: two full-time workers and 13 casuals; was evenly split by gender (seven males and eight females); included eight students; included two workers with dependants; had an even split between retail (seven) and hospitality (eight); and covered workers ranging in age from 20 to 38 years old. The incomes of the casuals were mostly in the range of \$400-650 per week. School-aged dependent students were not included because weekend work essentially represented the only available time for employment. Semistructured interviews (based around 13 primary questions) were conducted face to face and lasted approximately 45 minutes. Most questions were open-ended and designed to reveal the motivations for Sunday employment, including such potential factors as financial instability and the presence of penalty rates, underemployment, availability, or employer-based pressures. The interviews probed both general and specific motivations and attitudes surrounding Sunday employment.

In analysing the qualitative data, 'grounded theory' was applied to methodically scan for emergent themes, and factors underpinning the context in which 'choice' is exercised and motivations are fashioned with regard to Sunday work (Strauss \& Corbin, 1990). Rigorous thematic coding was implemented using highlighters, mind-mapping, graphs, and tables to systematically uncover relationships nested within the data; diary records of the interviews were also drawn upon to broaden the depth of the findings (Strauss \& Corbin, 1990; Yin, 2003). The interviewed cohort under-represented parents $(n=2)$ - who might especially value weekends for uninterrupted periods of familial interaction, especially if their children attend 
school during the week (Pocock and Skinner, 2010) —and international students $(\mathrm{n}=1)$ —who may be vulnerable to exploitation due to language issues, poor knowledge of employment rights, and susceptibility to employer power through the operation of the visa system (Clibborn, 2015). As choice may be limited for the latter group and the disutility of Sunday work high for the former group, the qualitative data might overstate the degree of choice truly exercised by Sunday workers in the industry.

\section{The extent and economic impact of the penalty rates decision}

The LFS showed that, on average, through 2014-16, 1.1 million people were employed in the retail industry and 720,000 in accommodation and food services

Who are Saturday and Sunday workers?

From unpublished LFS data we also know that, over 2014-16, an average of 280,000 Australian employees in retail worked Sundays, representing 25 per cent of retail workers. Approximately 270,000 Australian employees in hospitality worked Sundays, representing around 38 per cent of hospitality workers. They also showed that, in retail trade, around 40 per cent of Sunday employees were casuals (employees without paid leave entitlements), as were 64 per cent in accommodation and food services. A majority of tertiary students who are employed work in either the retailing or hospitality industries. However, this did not mean that most people who work in those industries are tertiary students, let alone that they were not in need. Amongst retail employees who usually worked on Sundays: 34 per cent were 'dependent' students; 19 per cent were parents; 12 per cent were non-dependent children; 21 per cent were family members without dependents; and 13 per cent were non-family members or persons living alone. That is, the majority of retail employees who would be affected by 
changes to weekend penalty rates were not students, even though a significant minority were. Amongst those working on Saturdays and Sundays in retail trade, students are disproportionately found amongst casuals, but there is still a substantial minority of weekend casuals who are not students and who are in turn dependent on the money — as, also, are many students, as shown by Bexley et al. (2013). Changes in penalty rates in retail and hospitality affected not only tertiary students but also a significant number of people who are likely to be dependent on retail or hospitality employment as their sole source of income.

Amongst the regions, retail trade has the highest proportion of regional employment in Ballarat (where, according to LFS-derived employment data published by the then Employment Department, it is 14.2 per cent of regional employment) while accommodation and food services has the highest proportion of regional employment in Warrnambool and South West (8.2 per cent of regional employment) (Department of Employment 2016).

The effects of award non-compliance

For some employees, the reduction in Sunday penalty rates represents a reduction in the amounts they are entitled to and paid, while for others it represents a reduction in their entitlements but not in how much they are paid (that is, it is 'unpaid'). We approximated the incidence of non-compliance amongst employees using, as a starting point, data from the Fair Work Ombudsman (FWO) on non-compliance amongst businesses and on the types of noncompliance (cited in FWC 2017a, [2073-7]). We then applied a discount for the likelihood that the proportions of employees not receiving award entitlements in those industries is lower than the proportions of establishments recording breaches (breaches are more common 
on small workplaces, and not all workers in a business would be underpaid). So, for estimation, we assumed that the proportion of employees in an industry receiving less than their entitlements can be approximated as the sum of wages and penalties contraventions estimated in the FWO data, plus half the gap between that sum and all contraventions (that is, we assume that half of other firms with non-compliance problems such as inadequate records would be in firms that pay below-award wages), multiplied by two-thirds. These numbers generate necessarily rough approximations at best. However, this method implies that something around 15 per cent of penalty rates reductions for retail workers were unpaid, as were a little below 32 per cent in accommodation and food services, where the scope for exploitation of workers with a non-English speaking background, including through 'coethnicity', is higher (Clibborn 2015, Campbell, Boese, and Tham 2016, Velayutham 2013). If these numbers overstate the incidence of award non-compliance (for example, if two-thirds is too high) then the subsequent numbers will be conservative in slightly understating the direct impact of the penalty rates decision on paid entitlements.

Affected workers under awards, collective agreements or individual arrangements

In the retail industry, EEH showed that award reliance was higher than the national average, at 34.5 per cent of employees, and in accommodation and food services it was higher again at 42.7 per cent. In total, 370,000 non-managerial retail employees and 320,000 nonmanagerial employees in accommodation and food services were reliant on awards. Many retail employees entitled to penalty rates are not covered by awards but by collective agreements or individual arrangements. 
It seems highly likely that award reliance would be higher in non-metropolitan than in metropolitan regions, due to smaller average workplace size. Industry effects also have a geographic dimension. For example, in Victoria, both retail trade and accommodation and food services constitute a higher proportion of employment outside of Melbourne (totalling 18.8 per cent) than inside Melbourne (17.3 per cent).

The penalty rates decision directly affects those workers in retail and hospitality on awards, but it also is likely to affect the pay of workers in retail and hospitality on other instruments, that is on individual arrangements and collective agreements. This effect occurs through two mechanisms.

First, some non-award-reliant workers will be themselves receiving penalty rates, under the terms of either their collective agreement or their individual contract. While a collective agreement remains in force until it is cancelled or replaced, and an individual contract continues until it is renegotiated, unilaterally changed by management or is superseded by award movements, it is likely that the lower penalty rates will form the reference point for future negotiations when new agreements or contracts are negotiated. We estimated the numbers of non-award-reliant workers receiving penalty rates by subtracting the numbers of award-reliant workers receiving penalty rates from the numbers of all workers receiving penalty rates in each industry. In turn, the numbers of award-reliant workers receiving penalty rates are estimated by multiplying the incidence of Sunday work in each industry by the incidence of award-reliance, and subtracting the numbers of people receiving 'unpaid' penalty rates (due to non-compliance) mentioned above. Data from Australian Work and Life Index (AWALI) survey, a representative telephone survey undertaken for several years 
by the University of South Australia, are used to estimate the proportions of employees working unsociable hours and receiving penalty rates. From this, it appears that approximately 80,800 'non-award' retail employees ('non-award' being simply employees on collective agreements or individual arrangements) and 70,400 'non-award' hospitality employees receive penalty rates for Sunday work. In the absence of any information to the contrary, we distribute these between collective agreements and individual arrangements in direct proportion to those instruments' overall coverage with each of those industries. Hence we estimate that of the 80,800 'non-award' retail employees receiving penalty rates for Sunday work, around 46,400 are on collective agreements and 34,500 are on individual arrangements. Similarly, of the 70,400 'non-award' hospitality employees receiving penalty rates for Sunday work, around 43,800 are on collective agreements and 26,600 are on individual arrangements.

Second, even when penalty rates are absorbed into loaded rates in a registered enterprise agreement and not directly paid, they form part of the Better Off Overall Test (BOOT) below which enterprise agreements cannot legally pay. When award penalty rates fall, the benchmark for the BOOT test also falls and so, in the long run, wage increases are likely to be lower. Likewise, even if an individual contract does not explicitly provide for penalty rates, a worker on an individual contract cannot receive less than they would be entitled to under the award. So, when penalty rates fall, future individual contracts can provide for lower wages than would otherwise be the case.

In both industries, EEH data reveal that, on average, collective agreements pay little or nothing more than awards (this is quite different to most other industries), and so changes to penalty rates in awards are highly likely to affect collective agreements through the operation 
of the BOOT. We can estimate how many by subtracting the number of collective agreement-covered Sunday workers receiving penalty rates in an industry (estimated earlier) from the estimated number of all Sunday workers on collective agreements (calculated by the incidence of Sunday work multiplied by the incidence of collective agreements in an industry). This gives us around 53,800 employees nationally who appear to be on retail collective agreements that do not contain penalty rates but in which Sunday penalty rates are relevant to the BOOT. Similarly, 56,800 are on hospitality collective agreements that do not contain penalty rates but in which Sunday penalty rates are relevant to the BOOT. Using a similar technique it appears that around 55,800 non-managerial Sunday retail employees are on individual arrangements that are potentially influenced by cuts in penalty rates and 45,800 non-managerial Sunday hospitality employees are on individual arrangements that are potentially influenced by cuts in penalty rates.

So, our estimate of the number of award-reliant non-managerial Sunday workers receiving penalty rates (after making the above deductions for non-compliance) is around 78,100 in retail and 81,800 in hospitality. To that we can add estimates of indirect reliance via collective agreements and individual arrangements, giving totals of 158,900 retail employees and 152,200 hospitality employees (that is, a total of 300,000 workers in the two industries) directly and indirectly affected by the changes to Sunday penalty rates. Their pay rates are likely to be influenced over the medium term by the changes in penalty rates under awards, as agreements are renegotiated. (Approximately another 50,000 should have been directly affected, but were not, because of award non-compliance.) Larger numbers would be affected, though less frequently, by changes in public holiday penalty rates. We must add a caveat though: it is difficult to know how many retail or hospitality employees working on Sundays are reliant on awards, not only because of sampling error but also because data on 
award coverage (including managerial status) and weekend work are from different sources (and, for example, managers and non-managers have different likelihoods of doing shiftwork) (Australian Bureau of Statistics 6342.0).

Impact on pay rates and daily wages

In most awards where reductions have occurred, the reductions in Sunday rates are equivalent to a cut of 13 to 17 per cent in hourly pay, but in the Retail Award the reduction for permanent workers is equivalent to 25 per cent of hourly pay. The Retail Award (with a 25 per cent cut for permanent workers, and a 14 per cent cut for casuals) and the Hospitality Award (with a 14 per cent cut for permanent workers) are very likely the two largest awards under consideration here. Cuts in public holiday penalty rates are consistently equivalent to a 9 to 10 per cent reduction on previous Sunday hourly pay rates. Many reductions are worth around $\$ 5$ per hour, though the lowest reduction for adult permanent employees on the large Retail Award is closer to $\$ 10$ per hour at the lower end of the classification scale, growing to $\$ 12$ per hour for higher level retail employees, and the reductions for permanent workers on the Pharmacy Award range from $\$ 10$ to $\$ 16$ per hour.

In the absence of more recent published data, a 1992 time use survey suggested that employees work around 5.5 hours per Sunday (Australian Bureau of Statistics 4153.0). It is plausible that Sunday working hours have increased since then, but we have no way of estimating if and by how much, and so our estimates here are likely to be conservative. For 5.5 hours work, the losses for an affected Sunday employee in the hospitality industry would range between $\$ 25$ and $\$ 31$ per day. The losses for an affected Sunday employee in the retail 
trade industry working 5.5 hours would range between $\$ 31$ and $\$ 65$ per day (but would be higher for higher classification employees under the Pharmacy Award). On public holidays, the losses for an affected employee in either industry working 5.5 hours would range between $\$ 25$ and $\$ 33$ per day (but again would be higher for higher classification employees under the Pharmacy Award).

Although the FWC recognised that a substantial proportion of the affected workers were low paid, it took the view that 'the primary purpose of such penalty rates is to compensate employees for the disutility associated with working on public holidays rather than to address the needs of the low paid' (FWC 2017a at [1929]). It might be argued that the FWC subsequently showed its concern for this group by being more generous than expected with its minimum wage decision a few months later (Fair Work Commission 2017b). This formulation is untestable. However, even the minimum wage decision was a few tenths of a percentage point more generous than it would otherwise have been, this would be far less than needed to compensate low wage retail and hospitality workers for their income losses associated with the total impact of the penalty rates decision. To fully compensate them (that is, to raise minimum wages by $\$ 25-65$ per week more than they would otherwise have done) would be very expensive for employers, many of whom would not have been employing retail and hospitality workers anyway, and so it would have been extremely inefficient compensation. It seems unlikely the FWC would have tried to achieve such a balance given that no balance was feasible. Perhaps the more notable aspect of the later decision was that a Bench, containing three of the five members that had been on the penalty rates Bench, conceded that its pervious approaches to disemployment effects of minimum wage increases 'may have been overly cautious' (FWC 2017b at [9]). 
Impact on weekly pay after accounting for possible employment effects

The main justification for the reductions in penalty rates was the (increasingly uncertain) increase in employment that would result. There is evidence that no significant employment gains would materialise (Yu 2015). However, we should also consider the hypothetical consequences if there are positive employment effects. Econometric research suggests that an increase in the number of hours worked in the industry is a more plausible consequence of reduced penalty rates than an increase in the total number of jobs (Yu and Peetz 2018). No employer evidence to the FWC proceedings on penalty rates suggested that there would be a reduction in prices flowing from them (FWC 2017a at [632]), implying again that employment effects would be muted. While we do not seek to quantify employment effects, we take account of a range of plausible offsetting impacts by considering several scenarios. There are two reasons for this. First, if there are employment effects, especially through increased hours worked by existing employees (the most plausible response-ibid), then those existing Sunday workers would work longer hours which might offset the drop in hourly wages, so we need to estimate the size of possible net effects. Second, if there were still a net fall in income, the decision would represent an unambiguous transfer of income from labour to capital, even after employment effects. This would contrast the claims of the Productivity Commission who claimed there would be no increase in profits for employers (Productivity Commission 2015, 466).

Again, leaning towards conservative estimates, we tested the effects of elasticities of hours worked by workers on penalty rates with respect to the value of penalty rates of: $-0.5,-0.3,-$ 0.1 and 0 . This range of plausible scenarios for the elasticity of employment with respect to wages comes from an extensive analysis by Lichter, Siegloch, and Peichl (2014). That is, we 
assumed employment would increase under each of the four scenarios according to the elasticities stated above, and this assumed increase in employment increases Sunday earnings and reduces net earnings losses (again, assuming it leads to greater hours amongst those working Sundays). The greater the absolute value of the elasticity, the smaller the net earnings loss. The numbers discussed below reflect the ranges bookended by the extremes (0.5 to 0$)$.

Depending on which elasticity scenario is assumed, for an average level 1 employee under the retail award, total Sunday earnings would fall by between 16 per cent and 25 per cent, a result of the combined effect of a 25 per cent drop in hourly pay and an increase in hours worked of up to 0.5 hours or 12.5 per cent. This corresponds to earnings losses ranging from $\$ 33$ to $\$ 53$ per week, for an employee working for 5.5 hours on a Sunday before the penalty rate changes take effect. For low-classification workers on public holidays, the earnings losses range from 5 per cent to 10 per cent, depending on the elasticity assumed. For highclassification employees under many awards shown in Table 18, the dollar value of the loss ranges from $\$ 15$ to $\$ 37$. However, for high-classification permanent employees under the Pharmacy Award the losses begin around $\$ 55$ on the most optimistic of the elasticity scenarios, and for high-classification permanent employees under the common Retail Award the losses begin at $\$ 30$ on the most optimistic of the elasticity scenarios and range up to $\$ 48$ per week where elasticity is zero. Losses range from $\$ 14$ to $\$ 27$ per holiday, for a lowclassification employee working for 5.5 hours on a public holiday before the penalty rate changes take effect, and from $\$ 15$ to $\$ 44$ for higher-classification employees.

The above scenarios assume a labour demand effect, but a labour supply effect is at least as likely. With lower wages, some workers will cease to offer themselves for Sunday work, and 
their places may be taken by other workers - perhaps increased hours offered by existing workers. The next section will illustrate how constrained the former group are in withdrawing their labour, but some would still be likely to do it. Regardless, the net transfer of income from labour to employers is not materially changed by this supply-side behaviour, though a greater number of employees (some becoming former employees) would suffer a reduction in income, while some new employees could be added to the payroll.

\section{Impact on annual earnings}

To calculate annual earnings losses, we multiply weekly losses by 52 . For low-classification employees working 5.5 hours per Sunday, annual earnings losses due to changes in penalty rates range from around $\$ 750$ to $\$ 1600$ in hospitality and from $\$ 900$ to $\$ 2800$ in the retail industry, depending on the award and the assumed elasticity. For high classification employees working 5.5 hours per Sunday, lost earnings due to penalty rates changes range from $\$ 900$ to $\$ 1600$ in hospitality, from $\$ 1100$ to $\$ 3400$ in retail trade, and from $\$ 1400$ to \$4600 in pharmacies. Any Sunday workers separately working public holidays would experience further annual reductions, due to changes in public holiday penalty rates.

We calculate aggregate losses by multiplying the annual losses to employees by the number of employees. Assuming Sunday employees in hospitality and retail work an average of 5.5 hours on Sundays, the total direct earnings losses across the two industries are between $\$ 220$ million and $\$ 370$ million respectively, depending on the elasticity assumed. A minority (a bit over one fifth) of these losses are 'unpaid', but the majority are 'paid' losses. The total potential (direct and indirect) losses over the medium term across the two industries, if Sunday employees work an average of 5.5 hours on Sundays, could range from $\$ 520 \mathrm{~m}$ to $\$ 1$ 
billion, again depending on assumed elasticity, though the extent to which potential losses translate into actual losses is unknown.

\section{Impact on earnings equity}

At an individual level, EEH showed that employees in the retail and hospitality industry were the lowest paid in the country. Because of this, reducing earnings of this group would necessarily increase the inequality of the distribution of individual earnings, whether measured on an hourly or weekly basis and whether referring to full-time workers or to all workers. Meanwhile, data from the Household Income and Labour Dynamics in Australia (HILDA) survey (a large annual longitudinal household survey) showed that households containing any adult retail employees are worse off than other households by a range of measures, including wage and salary income, gross income, expenditure on non-discretionary items, ability to access financial resources in an emergency and ability to pay bills on time (Watson 2015). There is no reason to believe that the situation would be reversed for hospitality employees. Reductions in penalty rates would therefore have the effect of widening both the inequality of individual earnings and the inequality of household earnings.

A reduction of penalty rates in those industries will widen the overall gender pay gap (the ratio of female to male hourly earnings). The reason is that it will have a disproportionate impact on women. While males made up approximately 55 per cent of permanent full-time employees in both the retail and hospitality industries, females dominated permanent parttime and casual employment in both, comprising 61 to 66 per cent of casual employees and 69 to 76 per cent of permanent part-time employees. Women make up the majority of Sunday employees in both industries. That said, the effect on the all-industry gender gap is 
probably not large: modelling of earnings distributions with and without the penalty rates cut indicates that its order of magnitude is to add 0.1 percentage points to the gap in hourly average wage rates across the economy as a whole.

\section{Employee Choice}

In assessing the impact of penalty rate changes, we also take account of individual preferences and choices. This is because part of the rationale for changing penalty rates (aside from employment effects) is the idea that penalty rates for Sunday work are no longer relevant, because there is no disutility associated with it, as Sunday workers prefer to be working that day.

But let us consider our qualitative interviews in the context of the model presented earlier (Figure 1).

First, we observed was the difficulty of working on Sundays. The weekend workers whom we interviewed were, one way or another, averse to working on Sundays. This was because of the loss of social, familial, rest or leisure time. Seven interviewees explicitly desired to work fewer Sundays and more Saturdays and on other periods during the week. Respondents' aversion to Sunday work stemmed from the disruption to shared time they would otherwise have had with family, partners and friends. Said one:

It's already lame enough working a Sunday as it is, you know...you miss out on all the casual gatherings with friends and the fam. (JL, part-time student and casual retail) 
Another was 'really quite emotional sometimes' after missing time with her children because she felt compelled to 'drag' herself 'into work on occasional Sundays' in order to maintain living expenses or due to employer demands. (JS, casual)

A desire for more Saturday work and for less Sunday work was quite common amongst our interviewees. Many were unable to secure their preferred schedule, which would have involved working fewer Sundays. Said one:

I've been on this dodgy contract now for over six months and they knew I wanted to go on full-time when I started and made it seem like that would be possible...so I stuck around. It pisses me off because I know they can put more of us on full-time but like having us starved of hours so we'll work whenever. (JM, ongoing-casual retail worker)

Already in the above there are hints of the other elements of that model. The issue of employer control was very clearly mentioned by JM. Eight employees reported they had 'little control' of their employment schedule. Four had 'some control' (mostly students). Three were under the impression they exercised control over their schedule. One of those with low control said:

I was afraid my hours would get docked if I didn't agree to work Sundays....or that I would slip to the back of the boss's list of who gets called up first for the hours. (SD, casual hospitality worker and student)

Those with low autonomy reported that penalty rates were an essential element in accepting Sunday work. They mitigated negative effects of mostly involuntary Sunday employment. 
Often there was minimal room for negotiating Sunday schedules, and prospective employees felt agreeing to Sunday employment was necessary to securing employment. They generally felt compelled to work Sundays due to perceived potential employer retribution, including no longer being offered additional hours.

Even where respondents perceived some control, it was qualified. Three students that reportedly exercised control over their schedule and who saw Sunday work as 'kinda like any other day' (AC, casual hospitality worker) also had their availability largely curtailed through their studies. They were virtually incapable of working other times that could generate the same income they derived from Sunday work and admitted to relying upon penalties to meet living expenses. These employees said they would not work as many Sundays as they did in other circumstances.

Not all was bad. Some had positive perceptions that principally derived from their social cohesion at work - that is, they worked with close friends or partners. This may have added to those individuals' sense of control, supporting previous findings of Woodman (2012) and Craig and Brown (2014).

The qualitative interviews shed light on some other dimensions of Sunday work. The first was financial. Many respondents were convinced their incomes were inadequate. One said: I work Sundays for the pay, it massively helps me manage all my living expenses...but it is a bit of downer sometimes knowing you're stranded inside doing shit jobs whilst all your friends are at a barbeque or random gathering (TS, 20, casual hospitality worker). 
This was particularly the case for full-time students - contrary to ideas that, as 'non-career' employees, their needs were unimportant. (The FWC decision cut Sunday penalty rates in the fast food industry by substantially more for what it saw as 'non-career' than for 'career' workers.) One student said:

I have to say I'm most encouraged because of the money...I'm at a point where I rely on them to support my existence at the moment and I can only work very little because of study... and they rarely give me other days of work that I want. I have looked around but without luck...it's difficult to find the time to between work and uni as they are. So yeah...the money is my motivator! (LJ, 31, casual retail worker and student )

Sunday work, however, was seen as the way to 'boost the coffers' (JM). Amongst our interviewees, four workers were seeking full-time employment. Of these, three were already holding down multiple jobs.

Respondents were asked whether, if penalty rates were reduced, they would work as many Sundays as they do now. Some instead acknowledged they would be compelled to undertake increased Sunday employment, to compensate for the proposed reduction in Sunday premiums. SD, a casual hospitality worker and full-time student said:

I would despise working on Sundays for less pay while everyone else is out doing their thing, but you know...in my position I couldn't really do much about it. I'm so busy with study and things that I'd just have to suck it up though...there is really no chance for me to not be doing Sundays and I'd have to fuckin' do more of them to cover the hole in my wallet. 
SD was not alone. All the full time students reported they would probably have to work extra Sundays to cope financially, as did some part-time students. It appeared that, in certain cases, low-wage environments meant hourly wage cuts would lead to increased hours. Seven participants reported underemployment as a factor influencing Sunday work, of whom five were students and one had parental responsibilities. All these were dissatisfied with their schedules and stressed that they wanted more Saturdays and weekday work to cater to their flexibility needs:

If I could be regularly working say Thursday, Friday and Saturday, I could deal with it in a chunk then relax or see friends on Sunday and get uni work done if I have to. (LJ, casual retail worker and student)

The other working mother in the study (JS, casual hospitality employee) also desired a similar schedule so she could spend more time with her children. In order to supplement her husband's full-time employment she worked Thursdays, some Saturdays, and every second Sunday, however her weekend days were variable. She lamented that her ideal work routine would be to retain Thursdays and work consistent Saturdays, enabling he to balance childcare with her husband and interact more with her family on Sundays:

Having my Thursday and a Saturday would be nice though... my family and I would always then have a day (Sunday) to all get together and plan things a whole lot easier.

Underemployment is indeed a growing phenomenon in the Australian labour market. It is common amongst part-time workers. It has shown structural increases over time across the economy as part-time employment has grown. (The high rate of underemployment raises serious questions as to how useful a measure the unemployment rate is these days of labour 
market 'slack'.) Underemployment is most pervasive in the retail and hospitality industries (Australian Bureau of Statistics 4102.0). Over the triennium 2014-16, the average underemployment rate (underemployed persons as a proportion of all employed persons in an industry) was 16.2 per cent in retail trade and 20.3 per cent in hospitality (the industry with the highest rate of underemployment), compared to a national average of 8.8 per cent (Australian Bureau of Statistics 6291.0.55.003). Average rates in the preceding triennium (2011-13) were and 14.1, 17.8 and 7.7 per cent respectively, suggesting significant recent increases. Like the ABS data, these interviews showed that underemployment was common. This meant that casuals were particularly reliant on Sunday premiums to maintain their standard of living. Losses of penalty rates would lead to losses of income for many lowincome, non-students — as well as for students—with little capacity to respond.

This has implications for the labour supply effects mentioned earlier. On the one hand, lower Sunday penalty rates make Sundays less attractive for many of the interviewees. But their choices are constrained by several things affecting availability. So, many were in no position to exercise free choice over working on Sundays. Some were only available Sundays. A majority voiced concern about refusing Sunday work due to either job insecurity or the prospect of employer retribution or underemployment. As a result, many would work Sundays regardless of the change to award rates. This constrains the downward labour supply effects mentioned earlier. A possible net outcome is fewer people offering themselves for work (there is evidence that the participation rate is more responsive to wage changes in the conventional direction - that is, with a positive sign on the coefficient of elasticity — than is the number of hours per worker); but more hours being offered, or rather sought, by those people who remain in the labour market and who need a given income to get by (Evers et al 2008; Meyer 2018). This differential would be consistent with another study showing 
changing shift premiums in Australian retailing leading to no change in total employment but a small change in hours worked (Yu and Peetz 2018). That is, the theoretical effects of a cut in premiums on demand (positive) and supply (negative) might be small and offsetting in relation to the total number of employees, but mutually reinforcing in relation to the number of hours worked.

\section{Conclusions}

Overall, there are significant income losses arising from cuts to penalty rates in the retail and hospitality industries. Even allowing for debatable employment gains, in the average case Sunday employees would end up working longer hours for less total pay, and so would be

unambiguously worse off. In practice, some employees would not be offered any additional hours (and face a larger reduction in Sunday pay), while some others would have a greater increase in hours (and so face a smaller reduction, or possibly an increase, in Sunday pay).

The magnitude of effects can be illustrated as follows. Probably over 350,000 will be potentially affected, of which over 300,000 would have their actual pay eventually reduced and another 50,000 miss out because they were underpaid in the first place. Weekly losses for Sunday workers will mostly range between $\$ 25$ and \$65 per day, depending on their award, while public holiday workers might often, in rounded terms, lose $\$ 25$ to $\$ 35$ per holiday. The inequality of both individual and household earnings will increase. The total amount of income transferred from Sunday retail and hospitality workers to owners of capital will be between $\$ 0$. and $\$ 1.0$ billion. 
These estimates do not take account of any reductions in hours worked at other days of the week, due to any redistribution of hours from weekdays to Sundays. As no lay employer evidence indicated any reductions in prices, it is unlikely that overall demand for retail or hospitality services would increase, so it is plausible that any increase in Sunday hours would be partly or fully offset by reductions in hours on other days of the week.

We do not quantify all possibilities, such as the potential effects of 'loaded rates', or the potential effects of other future decisions on penalty rates outside the retail and hospitality sector. A loaded rate is 'a rate which is higher than the applicable minimum hourly rate specified in the modern award and is paid for all hours worked instead of certain penalty rates (such as the penalty rates for Saturday and Sunday work)'. At time of writing the FWC was considering their potential use in retail awards, in place of penalty rates, due in part to the incidence of award non-compliance. Any future move to 'loaded rates' would increase the variability of the losses, such that the greatest losses (above those previously discussed) would be experienced by people working public holidays (particularly holidays such as Christmas), and then by people working Sundays. While a reduction in penalty rates in the retail and hospitality sectors would likely increase pressures to eventually flow on reductions to other sectors, those potential effects are not estimated here.

The losses discussed above should be considered in the context of the disutility of working Sundays and public holidays. Those who work on Sunday have worse work life interference than other workers. Underemployment is most pervasive in the retail and hospitality workers. Qualitative research indicates that: many workers in retail and hospitality are under financial pressure; many have little 'control' over their employment schedule, with penalty rates an essential element in accepting Sunday work; many found Sunday work difficult 
because of disruption to shared time with others, and were generally averse to it because of the loss of social, familial, rest or leisure time. That said, some voiced concern about refusing Sunday work due to either job insecurity, the prospect of employer retribution or underemployment. They had low power in the employment relationship. The losses from penalty rate cuts are, it seems, concentrated on those with the lowest power.

These disutilities from the impact of Sunday work in the context of personal or family circumstances help us properly locate the relevance of choice to Sunday work. Those disutilities mean that, for most workers, a totally unhindered choice—an 'internal preference'-would often be to not work that day. So 'financial inducements' are used to try to persuade employees to work Sundays rather than another day. A critical factor is employer control, which can be strengthened by the existence of underemployment and possibly of low wages. The qualitative results here also suggest the need for further empirical research into the labour supply functions of low-wage, part-time workers, as the factors driving behavior (including the need to achieve a certain level of income to 'support [their] existence') may be quite different to those for middle and higher wage earners. It seems that lower penalty rates can lead to fewer people offering work, but those remaining 'choosing' to offer more hours per person, in an effort to retain some minimum living standard. Whether, in net terms, lower penalty rates would lead to more, or fewer, hours in total being offered by workers in the industry is hard to say; we can only say definitively that it would definitely lead to lower living standards for low wage earners and a redistribution of income upwards. 


\section{References}

Andrews, John Nevins. 1859. History of the Sabbath and First Day of the Week. Charleston SC: Nabu Press.

Australian Bureau of Statistics. 4102.0. Australian Social Trends

Australian Bureau of Statistics. 4153.0. Time Use. Canberra.

Australian Bureau of Statistics. 6202.0. Labour Force, Australia. Canberra.

Australian Bureau of Statistics. 6291.0.55.003. Labour Force, Australia, Detailed, Quarterly Canberra.

Australian Bureau of Statistics. 6306.0. Employee Earnings and Hours, Australia. Canberra: AGPS.

Australian Bureau of Statistics. 6342.0. Working Time Arrangements, Australia, November 2012. Canberra: AGPS.

Australian Bureau of Statistics. 6359.0. Forms of Employment. Canberra.

Baker, A., S. Ferguson, and D. Dawson. 2003. "The perceived value of time: Controls versus shiftworkers." Time and Society 12 (1):27-39.

Bexley, Emmaline, Suzanne Daroesman, Sophie Arkoudis, and Richard James. 2013. University student finances in 2012 A study of the financial circumstances of domestic and international students in Australia's universities. Melbourne: Centre for the Study for Higher Education, University of Melbourne and Universities Australia.

Bittman, Michael. 2005. "Sunday working and family time." Labour and Industry 16 (1):5981.

Burgess, John, and Duncan MacDonald. 1990. "The Labour Flexibility Imperative." Journal of Australian Political Economy 12:15-35. 
Campbell, Iain, Martina Boese, and Joo-Cheong Tham. 2016. "Inhospitable workplaces? International students and paid work in food services." Australian Journal of Social Issues 51 (3):279-298.

Campbell, Iain, and J Chalmers. 2008. "Job Quality and Part-Time Work in the Retail Industry: An Australian Case Study." International Journal of Human Resource Management 19:487-500.

Charlesworth, Sara, and Fiona Macdonald. 2015. Expert Report to the Shop Distributive and Allied Employees Association. In Four Yearly Modern Award Review 2014-2015: Penalty Rates Case ([2014] AM 305). Melbourne: Fair Work Commission.

Clibborn, Stephen. 2015. "Why undocumented immigrant workers should have workplace rights." Economic and Labour Relations Review 28 (3):465-473.

Craig, L., and J.E. Brown. 2014. "Weekend work and leisure time with family and friends: Who misses out?" Journal of Marriage and Family 76 (4):710-727.

Davis, Mark. 2007a. analysis of unreleased OEA data on AWAs May-September 2006, unpublished. Sydney.

Davis, Mark. 2007b. "Revealed: how AWAs strip work rights." Sydney Morning Herald, 17 April.

Dawkins, Peter, C Rungie, and Judith Sloan. 1986. "Penalty Rates and Labour Supply: Employee Attitudes to Non-Standard Hours of Work." Journal of Industrial Relations 28:564-587.

Deery, S. J., and A. Mahony. 1995. "Penalty Rates and Labour Supply: A Reply." Journal of Industrial Relations 37:302-305.

Department of Employment. 2016. "Employment projections for the five years to November 2020: Regional employment by ANZSIC Industry." Department of Employment Accessed 18/2/18. http://1mip.gov.au/default.aspx?LMIP/EmploymentProjections. 
Fair Work Commission. 2017a. 4 yearly review of modern awards - Penalty Rates. [2017] FWCFB 1001.

Fair Work Commission. 2017b. Annual Wage Review 2016-17. [2017] FWCFB 3501.

History Channel. 2017. Constantine decrees 'Sun-Day' as day of rest. In This day in History: Foxtel.

Kostiuk, P.F. 1990. "Compensating differentials for shift work." Journal of Political Economy 98 (5):1054-1075.

Lanfranchi, J., H. Ohlsson, and A. Skalli. 2002. "Compensating wage differentials and shift work preferences." Economic Letters 74 (3):393-398.

Lewis, Phil. 2015. "Paying the Penalty? The High Price of Penalty Rates in Australian Restaurants." Agenda: A Journal of Policy Analysis and Reform 21:5-26.

Lichter, Andreas, Sebastian Siegloch, and Andreas Peichl. 2014. The Own-Wage Elasticity of Labor Demand: A Meta-Regression Analysis. In Discussion Paper No. 14-016. Mannheim: Zentrum für Europäische Wirtschaftsforschung GmbH (Center for European Economic Research) (ZEW)

Lyons, Tim. 2015. "There may be non-economic considerations." Accessed 5. https://www.themonthly.com.au/blog/tim-lyons/2015/05/2015/1438744398/theremay-be-non-economic-considerations.

MacKinnon, J. B. 2015. "America's last ban on Sunday shopping." New Yorker. http://www.newyorker.com/business/currency/americas-last-ban-sunday-shopping. McIvor, Joseph, and Raymond Markey. 2017. "Scrutinising the argument for reducing penalty rates." Journal of Industrial Relations 59 (9):652-669.

Peetz, David. 2016. "The Productivity Commission and Industrial Relations Reform." Economic and Labour Relations Review 27 (2):164-180. 
Peetz, David, David Quinn, Leah Edwards, and Peter Riedel. 1993. "Workplace Bargaining in New Zealand: Radical Change at Work." In Workplace Bargaining in the International Context, edited by David Peetz, Alison Preston and Jim Docherty. Canberra: Department of Industrial Relations and Australian Government Publishing Service.

Pezzulo, L. 2015. The modern face of weekend work: survey results and analysis. . In Four Yearly Modern Award Review 2014-2015: Penalty Rates Case. Melbourne: Deloitte Access Economics.

Productivity Commission. 2015. Workplace RelationsFramework: Productivity Commission Inquiry Report, Volume 1. Canberra: PC.

Roan, Amanda, and C Diamond. 2003. "Starting Out: The Quality of Working Life of Young Workers in the Retail and Hospitality Industries in Australia." International Journal of Employment Studies 11:91-119.

Sands, Sean. 2015. Retail Award Research. Melbourne: Australian Consumer, Retail and Services research unit, Department of Marketing, Monash University.

Sharif, Mohammed. 2000. "Inverted "S" — The complete neoclassical labour-supply function." International Labour Review 139 (4):409-435.

Skinner, Natalie, and Barbara Pocock. 2014a. The Persistent Challenge: Living, Working and Caring in Australia in 2014. In The Australian Work and Life Index 2014. Adelaide: Centre for Work + Life, University of South Australia.

Skinner, Natalie, and Barbara Pocock. 2014b. The Persistent Challenge: Living, Working and Caring in Australia in 2014. In The Australian Work and Life Index. Adelaide: Centre for Work+Life, University of South Australia.

Velayutham, Selvaraj. 2013. "Precarious experiences of Indians in Australia on 457 temporary work visas." Economic and Labour Relations Review 24 (3):340-361. 
Watson, Ian. 2015. Employee Earnings in the National Retail Industry. Sydney: Report for the Shop Distributive and Allied Employee's Association.

Woodman, Dan. 2012. "Life out of Synch: How New Patterns of Further Education and the Rise of Precarious Employment Are Reshaping Young People's Relationships." Sociology 46:1074-1090.

Workplace Express. 2006. "Greenfields agreements true to predictions." Workplace Express, 13 November.

Yu, Serena. 2015. Evaluating the Impact of Sunday Penalty Rates in the NSW Retail Industry. In Report prepared for the Shop, Distributive and Allied Employees Association (SDA). Sydney: University of Sydney Business School.

Yu, Serena, and David Peetz. 2018. "Non-Standard TimeWage Premiums and Employment Effects: Evidence from an Australian Natural Experiment." British Journal of Industrial Relations forthcoming. 
Figure 1: Choice, control, inducements and weekend work.
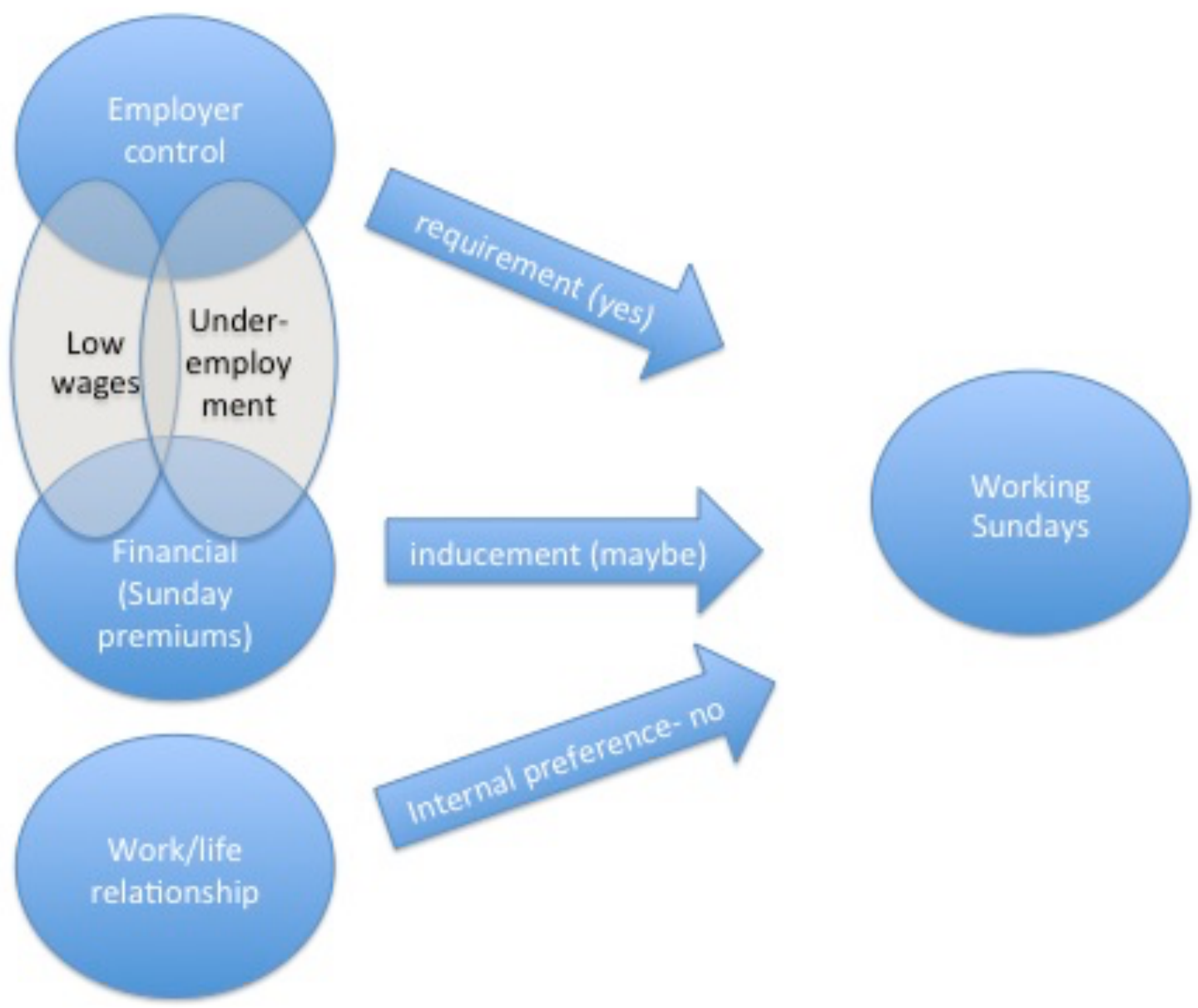